\title{
STRATEGI PEMERINTAH DALAM PENGELOLAAN LIMBAH PETERNAKAN \\ (STUDI DI DESA SENDANG KECAMATAN SENDANG KABUPATEN TULUNGAGUNG)
}

\section{THE ROLE OF THE VILLAGE GOVERNMENT IN DEALING WITH WASTE DAIRY FARM (STUDY IN SENDANG VILLAGE SENDANG DISTRICT TULUNGAGUNG REGENCY)}

\author{
Muharsono \\ ${ }^{1}$ Universitas Tulungagung, Tulungagung, Indonesia \\ muharsono212@gmail.com
}

\begin{abstract}
ABSTRAK
Salah satu usaha andalan sub sektor peternakan salah satunya adalah usaha peternakan sapi perah. Dalam kegiatan agroindustri yang memiliki peluang prospektif meruapakan subsistem agribisnis. Namun demikian, ada sisi negatif dari usaha peternakan sapi, yaitu menjadikan sumber pencemaran yang berasal dari limbah usaha peternakan sapi . Didalam penelitian ini bertujuan untuk untuk mengetahui, mendeskripsikan serta menganalisa peran Pemerintahan Desa dalam mengatasi pencemaran lingkungan akibat limbah peternakan sapi, ntuk mengetahui, mendeskripsikan dan menganalisa apa faktor penghambat dan faktor pendukung Peran Pemerintah Desa dalam mengatasi pencemaran lingkungan akibat limbah peternakan sapi. Penelitian ini menggunakan pendekatan kualitatif. Lokasi penelitian di Kabupaten Tulungagung yang berfokus di desa Sendang Kecamatan Sendang. Sumber data dalam penelitian ini adalah data primer dan data sekunder. Instrument penelitian dalam penelitian ini adalah peneliti sendiri, pedoman wawancara, catatan lapangan, dan kamera digital. Teknik pengumpulan data dalam penelitian ini adalah pengamatan, wawancara, angket, dan dokumentasi. Teknik analisis data dalam penelitian ini adalah dengan reduksi data, display data, dan menarik kesimpulan dan verifikasi. Dalam penelitian ini menggunakan keabsahan data. Peran pemerintah desa sebagai fasilitator yaitu memfasilitasi atau melengkapi kebutuhan, sarana dan prasarana yang mendukung proses pemerintahan dan pembangunan desa. Peran pemerintah desa sebagai mediator yaitu membuat suatu penyelesaian sengketa para pihak dengan kesepakatan bersama melalui mediator yang bersikap netral, dan tidak membuat keputusan atau kesimpulan bagi para pihak. Terakhir Pemerintah desa sebagai motivator yaitu Memberikan
\end{abstract}


Muharsono,

Strategi Pemerintah Dalam Pengelolaan Limbah Peternakan (Studi di Desa Sendang KAbupaten Tulunaggung)

motivasi-motivasi terhadap warga akan pentingnya melindungi alam dan lingkungan dari limbah pencemaran sapi perah.

\title{
Kata Kunci : Strategi, Pengelolaan, Limbah
}

\begin{abstract}
Dairy cattle business is one of the mainstays of the livestock sub-sector which has prospective opportunities in agro-industrial activities as one of the agribusiness subsystems. The development of this livestock business has a very positive impact on job creation and promises cash income, so that it can motivate people to take an active role in agribusiness activities to increase their family income. However, the dairy farming business does not only have positive values but can be a source of pollution from the dairy farming waste. This study aims to find out, describe and analyze the role of the Village Government in overcoming environmental pollution due to cattle farming waste to find out, describe and analyze what the inhibitting factors and supportting factors are the Role of Village Government in overcoming environmental pollution due to cow farm waste. This research uses a qualitative approach. The research location is in Tulungagung district which focuses on Krosok village, Sendang district, Tulungagung Regency. Sources of data in this study are primary data and secondary data. The research instrument in this study was the researcher himself, interview guidelines, field notes, and a digital camera. Data collection techniques in this study were observation, interviews, questionnaires, and documentation. Data analysis techniques in this study are data reduction, data display, and drawing conclusions and verification. In this study, the validity of the data is trust, transferability, dependability, and certainty. The results showed that: The role of the village government as a facilitator is to facilitate or complement the needs, facilities and infrastructure that support the process of government and village development. The role of the village government as a mediator is to make a dispute resolution between the parties by mutual agreement through a mediator who is neutral, and does not make decisions or conclusions for the
\end{abstract}


parties. Finally, the village government acts as a motivator, namely Providing Motivations for residents of the importance of protecting nature and the environment from dairy cow pollution.

\section{Keywords: Strategy, Management, Dairy Farm}

\section{PENDAHULUAN}

Kecamatan Sendang Kabupaten Tulungagung merupakan salah satu kecamatan yang ada di Tulungagung. Mayoritas penghasilanya adalah peternak sapi perah, Desa Sendang merupakan desa yang memiliki peternak sapi perah yang banyak. Akan tetapi, usaha sektor peternakan sapi perah tidak hanya memiliki nilai positif melainkan juga terdapat sisi nilai negatifnya yaitu dapat menjadi sumber pencemaran yang berasal dari limbah usaha peternakan sapi perah tersebut. Limbah peternakan adalah sisa buangan dari suatu kegiatan usaha peternakan seperti usaha pemeliharaan ternak. Limbah tersebut meliputi limbah padat dan limbah cair seperti feses, urin dan sisa buangan lainnya.

Masyarakat di Desa Sendang sendiri mulai banyak mengeluhkan akan penanganan limbah dari usaha peternakan sapi perah, karena ada beberapa oknum yang membuang limbah usahanya ke sungai, sehingga terjadi pencemaran lingkungan. Limbah peternakan yang dihasilkan oleh aktivitas peternakan seperti feses, urin, sisa pakan, serta air dari pembersihan ternak dan kandang menimbulkan pencemaran yang memicu protes dari warga sekitar. Berkaitan dengan hal tersebut, pemerintah desa Sendang mengupayakan penanganan yang tepat dengan mengatasi limbah ternak yang mengganggu masyarakat sekitar dan member keuntungan dalam penanganan tersebut. Dalam upaya penanganan limbah ini diperlukan karena tuntutan lingkungan yang nyaman tetapi juga karena pengembangan peternakan mutlak memperhatikan kualitas lingkungan, sehingga keberadaannya tidak menjadi masalah bagi masyarakat di sekitarnya.

Populasi peternakan sapi perah yang bertambah karena konsumsi susu sapi seamakin meningkat, jadi semakin banyak limbah yang harus diolah dengan baik agar menjadi manfaat dan 


\section{Muharsono,}

Strategi Pemerintah Dalam Pengelolaan Limbah Peternakan (Studi di Desa Sendang KAbupaten Tulunaggung)

nilai tambah bagi pemilik peternakan. Limbah dari usaha peternakan dapat berupa padatan dan cairan. Bentuk padatan terdiri dari feses/kotoran ternak, ternak yang mati, dan isi perut dari hasil pemotongan ternak.bentuk cairan terdiri dari urin ternak, air sisa pembersihan ternak maupun air dari sisa pencucian alat-alat ternak. Semakin bertambahnya populasi ternak sapi perah seiring dengan semakin meningkatnya kebutuhan konsumsi susu, akan menghasilkan banyak limbah yang harus ditangani.

Pada umumnya pencemaran lingkungan akibat limbah ternak sapi perah. Adanya pencemaran lingkungan akibat limbah usaha ternak sapi perah umumnya mendapat protes dari warga masyarakat yang terkena dampaknya, umumnya air sungai menjadi kotor, muncul penyakit kulit dan gatal-gatal serta menimbulkan bau yang tidak sedap. Kandungan dari limbah ternak sapi perah itu sendiri mengandung nutrisi atau zat padat yaitu jasad renik yang dihasilkan dari limbah ternak tersebut yang dapat menimbulkan pencemaran lingkungan. Pencemaran tersebut berupa bau yang tidak sedap yang ditimbulkan oleh gas, terutama gas amoniak $\left(\mathrm{NH}_{3}\right)$ dan gas Hidrogen Sulfida $\left(\mathrm{H}_{2} \mathrm{~S}\right)$. Kedua gas tersebut dalam konsentrasi tertentu akan mengganggu ternak dan peternaknya. Ternak yang menghirup kedua gas tersebut akan mengalami gangguan pada saluran pernafasan yang mengakibatkan ternak menjadi lebih peka terhadap serangan penyakit.

\section{KERANGKA TEORI}

\section{Pengertian Peran}

Pengertian peran merupakan suatu aspek dinamis dari kedudukan (status) yang dimiliki oleh seseorang, sedangkan status merupakan sekumpulan hak dan kewajiban yang dipunyai seseorang apabila seseorang melakukan hak-hak dan kewajiban-kewajiban sesuai dengan kedudukannya, maka ia menjalankan suatu fungsi.

Hakekatnya peran juga dapat dirumuskan sebagai suatu rangkaian perilaku tertentu yang ditimbulkan oleh suatu jabatan tertentu. Kepribadian seseorang juga mempengaruhi bagaimana 
peran itu harus dijalankan. Peran merupakan tindakan atau perilaku yang dilakukan oleh seseorang yang menempati suatu posisi di dalam status sosial. Peran yang dimainkan hakekatnya tidak ada perbedaan, baik yang dimainkan / diperankan pimpinan tingkat atas, menengah maupun bawah akan mempunyai peran yang sama.

\section{Pengertian Pemerintah Desa}

Menurut UU No 32 Tahun 2004 tentang pemerintah daerah menyatakan, desa atau yang disebut nama lain, selanjutnya disebut desa adalah kesatuan masyarakat hukum yang memiliki batas wilayah yang berwenang untuk mengatur dan mengurus kepentingan masyarakat setempat, berdasarkan asal usul dan adat istiadat setempat yang diakui dan dihormati dalam sistem pemerintahan negara kesatuan Republik Indonesia.

Pemerintahan desa merupakan bagian dari pemerintahan nasional yang penyelenggaraannya ditujukan pada pedesaan. Pemerintahan desa adalah suatu proses dimana usaha-usaha masyarakat desa yang bersangakutan dipadukan dengan usaha-usaha pemerintah untuk meningkatkan taraf hidup masyarakat. Lebih lanjut Pemerintahan Desa berdasarkan PP No. 47 Tahun 2015 adalah penyelenggaraan urusan pemerintahan dan kepentingan masyarakat setempat dalam sistem pemerintahan Negara Kesatuan Republik Indonesia. Pemerintahan desa terdiri dari Pemerintah Desa dan Badan Permusyawaratan Desa (BPD). Pemerintah Desa atau disebut dengan nama lain adalah Kepala Desa dan Perangkat Desa sebagai unsur penyelenggara pemerintahandesa. Pemerintah Desa terdiri dari kepala desa dan perangkat desa.

\section{Pengertian Limbah}

Pengertian pencemaran menurut SK Menteri Kependudukan Lingkungan Hidup No 02/MENKLH/1988 adalah masuk atau dimasukkannya mahluk hidup, zat, energi, dan/atau komponen lain ke dalam air/udara, dan/atau berubahnya tatanan (komposisi) air/udara oleh 


\section{Muharsono,}

Strategi Pemerintah Dalam Pengelolaan Limbah Peternakan (Studi di Desa Sendang KAbupaten Tulunaggung)

kegiatan manusia dan proses alam, sehingga kualitas air/udara menjadi kurang atau tidak dapat berfungsi lagi sesuai dengan peruntukkannya. Suatu kegiatan usaha peternakan menghasilkan limbah berupa kotoran baik berupa limbah padat dan cairan, gas, maupun sisa pakan. Limbah yang berbentuk padatan atau dalam fase padat (kotoran ternak, ternak yang mati, atau isi perut dari pemotongan ternak), limbah cair semua berbentuk cairan atau dalam fase cairan (air seni atau urine, air dari pencucian alat-alat), sedangkan limbah gas adalah semua limbah berbentuk gas atau dalam fase gas (Soehadji, 1992)

Pencemaran karena gas metan menyebabkan bau yang tidak sedap bagi lingkungan sekitar. Gas metan ini adalah salah satu gas yang bertanggung jawab terhadap pemanasan global dan perusakan ozon. Di Indonesia, emisi metan per unit pakan atau laju konversi metan lebih besar karena kualitas pakan yang diberikan rendah. Pemberian pakan dengan kualitas rendah maka, produksi metan juga meningkat (Suryahadi $d k k$., 2002). Limbah ternak masih mengandung nutrisi atau zat padat yang potensial untuk mendorong kehidupan jasad renik yang dapat menimbulkan pencemaran. Limbah peternakan sering mencemari lingkungan secara biologis yaitu sebagai media untuk berkembang biaknya lalat. Kandungan air manure antara 27-86 \% merupakan media yang paling baik untuk pertumbuhan dan perkembangan larva lalat, sementara kandungan air manure 65-85\% merupakan media yang optimal untuk bertelur lalat.

\section{METODE PENELITIAN}

Jenis penelitian yang digunakan adalah penelitian deskriptif dengan pendekatan kualitatif. Penelitian deskriptif adalah tema penelitian yang diangkat secara mendalam. Data yang dikumpulkan berupa kata-kata, gambar dan bukan angka-angka. Tujuan penelitian yang bersifat deskriptif adalah gambaran sifat-sifat individu, keadaan, gejala atau kelompok tertentu untuk menentuan atau penyebab suatu gejala atau gejala lain dalam masyarakat. Penelitian kualitatif adalah metode penelitian yang berlandaskan pada filsafat postpositifisme, digunakan untuk meneliti 
pada kondisi obyek yang alamiah dimana peneliti adalah sebagai instrumen kunci Sugiyono (2012). Penelitian Kualitatif ini dimaknai sebagai rangkaian kegiatan penelitian yang mengembangkan pola pikir induktif dalam suatu fenomena untuk menarik kesimpulan dari sesuatu yang bersifat khusus kepada yang sifatnya umum.

Penelitian dilakukan di Desa Sendang Kecamatan Sendang Kabupaten Tulungagung. Fokus pada unit penelitian Pada Pemerintah Desa Sendang akan diidentifikasi menggunakan metode berdasarkan nilai yang terbesar pada pelaksanaan penelitian dengan kawasan usaha ternak sapi perah yang meliputi area usaha ternak dan Pemerintah Desa Sendang di Kecamatan Sendang dilaksanakan mulai bulan Desember 2019 sampai dengan Juni 2020.

Teknik penentuan sampel menggunakan teknik porpusive sampling kategori judgement sampling. Menurut Kuncoro (2009), jika tujuan penelitian untuk mendapatkan informasi yang relavan dan tersedia dari sumber-sumber tertentu dan mencari informasi dari para ahli maka digunakan judgement sampling. Menurut Sugiyono (2011) Purposive sampling adalah teknik penentuan sampel dengan pertimbangan tertentu. Sedangkan kelompok sampel yang akan di interview adalah pakar-pakar (stakeholder) dan Pemerintah Desa Sendang dan pelaku usaha (peternak) sapi perah di Desa Sendang Kecamatan Sendang dalam penenilian ini adalah Stakeholder yang terdiri dari unsur pemerintah, pelaku usaha sapi perah dan akademisi. Jumlah sampel keseluruhannya adalah 15 orang. Sedangkan data sekunder akan ditelusuri melalui dokumen-dokumen dari instansi terkait, seperti, dokumen-dokumen perencanaan kabupaten serta Satuan Kerja Perangkat Daerah (SKPD) terkait, dan dokumen-dokumen lain yang relevan.

Sehubungan data tersebut maka sumber data dalam penelitian ini penulis menggunakan data primer yang diperoleh langsung dari lapangan dengan wawancara dengan Pemerintah Desa Sendang di Desa Sendang Kecamatan Sendang dan Masyarakat Desa Sendang. Penulis akan melakukan beberapa interview kepada para informan untuk mendapatkan data yang lengkap yang 


\section{Muharsono,}

Strategi Pemerintah Dalam Pengelolaan Limbah Peternakan (Studi di Desa Sendang KAbupaten Tulunaggung)

dapat menunjang penelitian ini. Selain itu data - data mengenai hasil produksi hewan dan hasil observasi juga dapat menjadi sumber data primer.

Sebagai tambahan penelitian ini juga membutuhkan sejumlah sumber data skunder yang diperoleh dari beragam buku. Buku - buku tersebut mengulas tentang peranan pemerintah desa dalam mengatasi limbah peternakan, berbagai refrensi itu akan bermanfaat untuk memperkaya wawasan penulis sehingga data yang diperoleh melalui observasi langsung ke lapangan menjadi mudah untuk dipahami dengan kerangka konseptual yang dipelajari.

Berkaitan dengan pertanyaan diatas, pengumpulan data dalam metode penelitian ini hanya menggunakan metode studi kepustakaan/studi dokumen, wawancara, dan pengamatan. Karena penelitian menggunakan penelitian kualitatif bukan kuantitatif. Oleh karena itu, metode daftar pertanyaan tidak diperlukan dalam pengumpulan data. Demi terjaminnya keakuratan data, maka peneliti akan melakukan keabsahan data. Data yang salah akan menghasilkan penarikan kesimpulan yang salah, demikian pula sebaliknya, data yang sah akan menghasilkan kesimpulan hasil penelitian yang benar. Menurut Bachri (2010), Keabsahan data yang digunakan penulis adalah dengan pendekatan triangulasi sumber untuk mengungkap dan menganalisis masalah-masalah yang dijadikan obyek penelitian. Dengan demikian analisis data menggunakan metode triangulation observers. Selanjutnya pendekatan triangulasi dilakukan menurut :

1. Sudut pandang Pejabat Dinas Lingkungan Hidup Kabupaten Tulungagung sebagai pihak pengarah dan pengawasan Tentang pengelolaan Limbah Kotoran sapi di Desa Sendang, Kecamatan Sendang;

2. Menurut sudut pandang Pemerintah Desa Sendang terkait mengatasi pencemaran lingkungan akibat limbah peternakan sapi perah.

3. Sudut pandang peternak terhadap Peran Pemerintah Desa Sendang terhadap Peternak Sapi Perah; dan. 
4. Sudut pandang masyarakat terhadap Pemerintah Desa Sendang tentangcara mengatasi pencemaran lingkungan akibat limbah peternakan sapi perah di Desa Sendang, Kecamatan Sendang.

\section{HASIL DAN PEMBAHASAN}

\section{Sejarah Kecamatan Sendang}

Sendang adalah sebuah kecamatan di Kabupaten Tulungagung, Provinsi Jawa Timur, Indonesia. Wilayah Kecamatan Sendang adalah lereng gunung wilis bagian selatan, banyak objek wisata di kawasan Kecamatan sendang, antara lain tempat wisatanya adalah: Pesanggrahan Argo Wilis di desa sendang, Candi Penampean, kebun Teh dan Air ternjun lawean di desa Geger, Air terjun Jurang senggani di desa Nglurup, air terjun Prongos di desa Nyawangan dan candi omban jago di desa Nyawangan tepatnya du dusun Sumberingin. Mayoritas penduduk kecamatan sendang berprofesi sebagai petani dan peternak sapi perah, karna posisi sendang di lereng gunung yang subur.

\section{Keadaan Geografi}

Secara geografis, Desa Sendang termasuk wilayah yang memiliki pegunungan . Letak Desa Sendang berada diantara 2 desa lain yang juga masih termasuk dalam wilayah Kecamatan Pagerwojo, Ketinggian dari Permukaan Laut adalah 520 m, Jarak ke Kecamatan 500 M dan Ke kabupaten kurang lebih 20 Km, jarak ke Propinsi Kurang lebih $175 \mathrm{Km}$, Berada di lereng selatan Gunung Wilis, Desa Sendang mempunyai suhu yang dingin, dengan potensi sumber mata air yang cukup melimpah untuk pengembangan wisata alam dan potensi agropolitan yang dapat dikembangkan oleh Desa. 


\section{Keadaan Topografi}

Desa Sendang terdiri dari 3 ( tiga ) dusun yaitu : Dusun Pabyongan, Dusun Bantengan dan Dusun Bringin dengan luas wilayah 928 Ha, luas hutan pangkuan desa 817 Ha dengan jumlah penduduk 4.867 Jiwa. Dahulu Desa Sendang merupakan desa dengan kombinasi wilayah lahan kering dan lahan basah di mana terdapat saluran irigasi untuk pertanian disi lain dan wilayah pertanian dengan tadah hujan untuk pertanian.

Tabel 4.2. Luas Wilayah Desa Sendang menurut Penggunaan Tanah

\begin{tabular}{|l|l|l|l|}
\hline No. & Jenis Penggunaan Tanah & Persentase(\%) & Luas (ha) \\
\hline 1. & Pemukiman & 25,6 & 54,25 \\
\hline 2. & Persawahan & 36,6 & 77,56 \\
\hline 3. & Perkebunan & 27,1 & 57,37 \\
\hline 4. & Ladang & 9,7 & 20.44 \\
\hline 5. & Kolam Ikan/Empang & 0,7 & 1,5 \\
\hline 6. & Lainnya & 0,3 & 0,61 \\
\hline \multicolumn{2}{|l|}{ Jumlah Luas Keseluruhan } & 100 & 211,73 \\
\hline
\end{tabular}

Sumber : Kantor Kepala Desa Sendang 2019

Struktur organisasi ialah susunan dari berbagai komponen atau unit kerja dalam suatu organisasi.Struktur organisasi lebih mengarah kepada pembagian kerja dan mengenai bagaimana fungsi dari berbagai kegiatan berbeda yang telah dikoordinasikan. Selain itu, struktur organisasi lebih menuju kepada berbagai spesialisasi dari suatu pekerjaan tertentu, termasuk saluran perintah atau penyampaian laporan.Struktur Organisasi dan Tata Kerja Pemerintah Desa berdasarkan Peraturan Bupati Nomor 48 Tahun 2017 pasal 1 adalah satu sistem dalam kelembagaan dalam pengaturan tugas dan fungsi serta hubungan kerja. Dengan arti lainnya Struktur organisasi merupakan suatu susunan atau hubungan terhadap 
berbagai komponen serta bagian dan juga posisi pada sebuah organisasi, disetiap komponen yang ada di dalam organisasi memiliki saling ketergantungan. Sehingga jika adanya suatu komponen yang baik maka akan berpengaruh kepada komponen lainnya dan tentunya juga akan berpengaruh terhadap organisasi tersebut.

\section{HASIL PENELITIAN}

Meningkatnya kebutuhan pangan Seiring dengan pertumbuhan penduduk yang semakin meningkat. Tidak hanya karbohidrat, pertumbuhan manusia juga membutuhkan protein hewani yang didapat dari sektor peternakan. Hasil peternakan mulai berkembang dan tumbuh dari waktu ke waktu. Begitu pula yang ada di desa Sendang, hampir 70 persen penduduk desa ini mempunyai usaha sapi perah baik sebagai mata pencaharian utama atau hanya usaha sampingan.

Akan tetapi, selain memiliki dampak positif yaitu dapat meningkakan kesejahteraan penduduk usaha peternakan sapi perah juga membawa dampak negatif. Selain memperoleh keuntungan dalam hal bisnis, usaha peternakan juga menimbulkan dampak negatif bagi lingkungan dan kesehatan masyarakat. Limbah yang langsung dibuang ke lingkungan tanpa diolah akan mengkontaminasi udara, air dan tanah sehingga menyebabkan polusi. Limbah ternak sebagai faktor negatif dari usaha peternakan adalah fenomena yang tidak dapat dihilangkan dengan mudah. Eksternalitas negatif yang timbul dari pengembangan peternakan sapi perah bersumber dari kotoran sapi perah yang dapat mengeluarkan gas methan bahan pencemar udara, kotoran ternak sebagai sumber mikroorganisme yang mengganggu kesehatan lingkungan dan bau yang dapat mengganggu kenyamanan manusia.Peternakan sapi yang melebihi 20 ekor wajib untuk melakukan evaluasi dampak lingkungan. Hal ini juga tidak luput dari perhatian pemerintah desa Sendang.Pemerintah desa menyadari bahwa harus ada aksi yang signifikan untuk 
mengatasi masalah pencemaran yang diakibatkan oleh usaha peternakan sapi perah ini. Pemerintah desa melakukan beberapa upaya antara lain adalah sebagai berikut :

a. Pemerintah Desa Sebagai Fasilitator (Dukungan)

Sesuai dengan Undang - Undang nomor 32 Tahun 2009 tentang Perlindungan dan Pengelolaan Lingkungan Hidup, maka setiap usaha disamping mendapatkan keuntungan atau profit hendaknya juga menjaga kelestarian lingkungan dengan meminimalkan timbulnya limbah bahkan mengolah limbah hingga menjadi produk yang bernilai. Limbah akan dapat diatasi dan bisa menjadi bukan lagi sebuah masalah, bahkan dari limbah dapat menjadi sesuatu yang bermanfaat jika dikelola dengan baik dan benar.

Hal ini sangat disadari oleh pemerintah desa Sendang sehingga pemerintah desa berusaha untuk memberikan bantuan kepada para peternak sapi perah untuk mengatasi pencemaran limbah ternak sapi perah tersebut. Beberapa upaya dilakukan oleh pemerintah desa dengan melakukan kerja sama dengan pihak - pihak yang terkait.

Seperti hasil wawancara dengan kepala desa Sendang bapak Agil Wuisan :

“ kami ( pemerintah desa ) sangat menyadari bahwa sangat penting untuk membantu para peternak dalam menangani masalah pencemaran limbah sapi perah ini. Karena kalau tidak segera ada solusi penangannya akan sangat menggangu bagi semua pihak. Karena kantidak semua penduduk desa adalah peternak sapi perah tho mas, jadi pastilah akan ada yang protes kalau tidak segera ditangani meski selama ini belum ada laporan dari warga terkait hal tersebut.” ( wawancara pada hari kamis,4 Juni 2020 ).

Lebih lanjut terkait hal ini juga disampaikan oleh sekretaris desa yaitu bapak Priyono : “yang sudah kami lakukan beberapa waktu ini adalah mengadakan pelatihan pembuatan biogas kepada para peternak sapi perah mas. Yang mengadakan pelatihan itu biasanya dari Dinas Pemberdayaan Masyarakat Desa ( DPMD ) lalu ada lagi dengan dinas 
peternakan juga dari pihak kecamatan. Dan kami sangat mendukung sekali pelatihan seperti ini.’( wawancara pada hari jumat,5 Juni 2020 )

Dari hasil wawancara di atas bisa diketahui bahwa upaya pemerintah desa sebagai fasilitator adalah dengan memberi dukungan penuh terhadap upaya penanggulangan pencemaran limbah ternak sapi perah dengan menjalin kerja sama dengan pihak - pihak terkait yaitu dinas pemberdayaan pemerintah desa, dinas peternakan dan juga kecamatan untuk mengadakan pelatihan pembuatan biogas.

Perlu kita ketahui bahwa Limbah ternak masih mengandung nutrisi atau zat padat yang potensial untuk mendorong kehidupan jasad renik yang dapat menimbulkan pencemaran. Suatu studi mengenai pencemaran air oleh limbah peternakan melaporkan bahwa total sapi dengan berat badannya $5.000 \mathrm{~kg}$ selama satu hari, produksi manurenya dapat mencemari $9.084 \times 10^{7} \mathrm{~m}^{3}$ air. Selain melalui air, limbah peternakan sering mencemari lingkungan secara biologis yaitu sebagai media untuk berkembang biaknya lalat. Kandungan air manure antara 27-86 \% merupakan media yang paling baik untuk pertumbuhan dan perkembangan larva lalat, sementara kandungan air manure 65-85\% merupakan media yang optimal untuk bertelur lalat.

Kehadiran limbah ternak dalam keadaan keringpun dapat menimbulkan pencemaran yaitu dengan menimbulkan debu. Pencemaran udara di lingkungan penggemukan sapi yang paling hebat ialah sekitar pukul 18.00, kandungan debu pada saat tersebut lebih dari $6000 \mathrm{mg} / \mathrm{m}^{3}$, jadi sudah melewati ambang batas yang dapat ditolelir untuk kesegaran udara di lingkungan $\left(3000 \mathrm{mg} / \mathrm{m}^{3}\right)$.

Salah satu akibat dari pencemaran air oleh limbah ternak ruminansia ialah meningkatnya kadar nitrogen. Senyawa nitrogen sebagai polutan mempunyai efek polusi yang spesifik, dimana kehadirannya dapat menimbulkan konsekuensi penurunan kualitas perairan sebagai akibat terjadinya proses eutrofikasi, penurunan konsentrasi oksigen 
terlarut sebagai hasil proses nitrifikasi yang terjadi di dalam air yang dapat mengakibatkan terganggunya kehidupan biota air.

b. Pemerintah Desa Sebagai Mediator (Mediasi)

Dalam kehidupan sehari-hari banyak di temukan Sengketa antar warga misalnya perebutan lahan untuk sektor perkebunan, persaingan usaha tidak sehat untuk sektor industry, atau perebutan pembibitan untuk peternakan dan perikanan. Sengketa atau pun masalah yang melibatkan dinamika sosial budaya ini haruslah dikelola dengan baik agar terhindar dari konflik yang lebih besar dan meluas. Oleh karena itu diperlukan suatu mekanisme yang tepat untuk menyelesaikan sengketa antar warga ini. Juga perlu adanya antisipasi sengketa yang akan bermuara kepada konflik komunal masyarakat. Salah satu metode yang memberikan solusi kemenangan bagi pihak yang bertikai adalah melalui jasa mediasi. Dan yang paling sesuai untuk menjadi mediator dalam hal ini adalah pemimpin wilayah misalnya kepala desa, yang mengerti betul akan kondisi warganya dan tentunya dihormati oleh warganya.

\section{c. Pemerintah Desa Sebagai Motivator}

Kepemimpinan merupakan sekumpulan dari serangkaian kemampuan dan sifat-sifat kepribadian, termasuk didalamnya kewibawaan, untuk dijadikan sebagai sarana dalam rangka menyakinkan yang dipimpinnya agar mereka mau dan dapat melaksanakan tugastugas yang dibebankan kepadanya dengan rela, penuh semangat, ada kegembiraan batin, serta merasa tidak terpaksa. Peran pemerintah desa sebagai motivator artinya menggerakkan partisipasi masyarakat jika terjadi kendala-kendala dalam proses pembangunan untuk mendorong dan memelihara dinamika pembangunan desa. Pemerintah berperan melalui pembuatan program yang sesuai dengan aspirasi masyarakat. Dalam hal ini pemerintah desa Sendang sudah berupaya untuk memotivasi masyarakatnya di dalam penanggulangan pencemaran limbah sapi ternak. 
2. Faktor Penghambat dan Faktor Pendukung Strategi Pengelolaan Pemerintah dalam Pencemaran Limbah di Desa Sendang Kecamatan Sendang Kabupaten Tulungagung.

Dalam setiap keputusan ataupun upaya yang dilakukan oleh setiap pemerintahan pasti ada faktor-faktor yang menjadi pendorong terlaksanya program atau upaya tersebut.Akan tetai, pasti juga ada beberapa hal yang malah menghambat tercapainya sebuah program atau upaya yang dilakukan.

\section{A. PEMBAHASAN}

\section{Strategi Pemerintah dalam Pengelolaan Pencemaran Lingkungan Akibat Limbah Peternakan di Desa Sendang Kecamatan Sendang Kabupaten Tulungagung.}

a. Peran pemerintah desa sebagai fasilitator, bahwa kepala desa menjalankan perannya sebagai fasilitator dalam hal memfasilitasi atau melengkapi kebutuhan, sarana dan prasarana yang mendukung proses pemerintahan dan pembangunan desa. Fasilitator juga dapat di katakan sebagai seorang melakukan fasilitas, yakni membantu mengelola suatu proses pertukaran informasi, memperlancar komunikasi, dan memecahkan masalah bersama-sama. Fasilitator bukanlah seseorang yang bertugas hanya memberikan pelatihan, bimbingan nasihat atau pendapat. Fasiltator harus menjadi narasumber yang baik untuk berbagai permasalahan.

Kepala Desa sebagai fasilitator desa merupakan pendamping masyarakat dalam pelaksanaan serta meningkatkan program-program pembangunan desa, artinya seorang fasilitator harus mampu menyediakan dan siap dengan informasi termasuk pendukungnya. Peran Kepala Desa Sendang sebagai fasilitator cukup membantu masyarakat desa moncongloe, hal ini terlihat dari hasil wawancara dengan tiga informan yang mengatakan bahwa kepala desa sangat membantu dalam memecahkan masalah pembangunan desa. Dalam hal upaya penanganan pencemaran limbah ternak sapi peerah pemerintah desa 
Mulyosari telah menjalankan fungsinya sebagai fasilitator yaitu menyediakan sarana untuk menyelesaikannya dengan mendatangkan pihak-pihak terkait yaitu dari dinas pembedayaan masyarakat desa, dinas peternakan dan dari pihak kecamatan untuk mengadakan pelatihan menolah limbah ternak sapi perah menjadi seuatu yang lebih bermanfaat. Upayanya antara lain adalah sebagai berikut :

\section{Pengomposan}

Kompos merupakan hasil pelapukan bahan-bahan berupa kotoran ternak/feses, sisa pertanian, sisa pakan dan sebagainya. Proses pelapukan dipercepat dengan merangsang perkembangan bakteri untuk menghancurkan menguraikan bahan-bahan yang dikomposkan. Penguraian dibantu dengan suhu 600C. Proses penguraian mengubah unsur hara yang terikat dalam senyawa organik sukarlarut menjadi senyawa organik larut yang berguna bagi tanaman (Ginting, 2007).

Bokashi adalah suatu kata dalam bahasa Jepang yang berarti bahan organik yang telah difermentasikan, pupuk ramah lingkungan dan termaksud bahan organik kaya sumber kehidupan. Ciri-ciri pupuk bokashi yang baik warna coklat kehitam-hitaman, bahan hancur, lembab tidak keras dan tidak bau, bau seperti tanah atau humus (Indroprahasto, 2010)

\section{Biogas}

Biogas adalah suatu jenis gas yang bisa dibakar, yang diproduksi melalui proses fermentasi anaerobic bahan organic seperti kotoran ternak dan manusia, biomassa limbah pertanian atau campuran keduanya, di dalam suatu ruang pencerna (digester).Sistim produksi biogas juga mempunyai beberapa keuntungan seperti (a) mengurangi pengaruh gas rumah kaca, (b) mengurangi polusi bau yang tidak sedap (Nurhasanah, 2005). Menurut Willyan (2008), menyatakan bahwa biogas (gas bio) merupakan gas yang ditimbulkan jika bahan-bahan organik, seperti kotoran hewan, kotoran mausia, atau sampah, direndam didalam air dan disimpan di dalam tempat tertutup atau anaerob. Proses terjadinya biogas 
adalah fermentasi anaerob bahan organik yang dilakukan oleh mikroorganisme sehingga menghasilkan gas yang mudah terbakar. Secara kimia, reaksi yang terjadi pada pembuatan biogas cukup panjang dan rumit, meliputi tahap hidrolisis, tahap pengasaman, dan tahap metanogenik.

Pelatihan yang difasilitasi oleh pemerintah desa Sendang dengan mendatangkan nara sumber ahli bertujuan agar permasalahan terkait pencemaran yang diakibatkan limbah ternak sapi perah bsa teratasi, selain itu juga agar limbah ini bisa berhasil guna. Misalnya biogas yang dihasilkan diharapkan bisa dipasarkan sehingga mempunyai nilai ekonomis.Pemerintah desa sebagai fasilitator bertugas untuk menyediakan fasilitas yang dibutuhkan. Limbah ternak atau kotoran ternak dapat dijadikan sebagai pupuk organik.Masyarakat di desa Sendang sudah biasa menggunakan pupuk kandang sebagai pupuk tanaman, tanpa pengolahan terlebih dahulu. Pupuk kandang jika tanpa pengolahan bisa menimbulkan masalah terutama hama dan penyakit pada tanaman, hal ini karena pupuk kandang yang belum diolah bisa tumbuh jamur, bakteri dan serangga yang dapat menggangu pertumbuhan tanaman. Oleh karena itu perlu pengolahan limbah ternak berupa kotoran menjadi pupuk organik. Selain pembuatan pupuk organik dari limbah ternak dapat bermanfaat untuk menyuburkan tanah. Pengolahan limbah ternak menjadi pupuk organik juga dapat bermanfaat mengurangi pencemaran lingkungan.Sehingga diharapkan dapat menghilangkan atau meniadakan dampak potensial terhadap lingkungan yang dianggap tidak relevan, terutama bau dan lalat.Agar tercapai pelingkupan sesuai batas ekologis yaitu, ruang penyebaran dampak dari suatu rencana usaha atau kegiatan dari media transportasi limbah. Hal tersebut yang mendasari langkah pemerintah desa sebagai fasilitator dengan tujuan baik bagi peternak sapi peerah maupun masyarakat yang bukan peternak sapi ternak bisa hidup saling berdampingan dengan rukun dan damai. 
b. Peran Pemerintah Desa Sebagai Mediator

Secara etimologi, istilah mediasi berasal dari bahasa Latin, mediare yang berarti berada di tengah. Makna ini menunjuk pada peran yang ditampilkan pihak ketiga sebagai mediator dalam menjalankan tugasnya menengahi dan menyelesaikan sengketa antara para pihak. "Berada di tengah" juga bermakna mediator harus berada pada posisi netral dan tidak memihak dalam menyelesaikan sengketa. Ia harus mampu menjaga kepentingan para pihak yang bersengketa secara adil dan sama, sehingga menumbuhkan kepercayaan (trust) dari para pihak yang bersengketa. (atriagovernmentunhas09.blogspot.com) Secara umum mediasi dapat diartikan upaya penyelesaian sengketa para pihak dengan kesepakatan bersama melalui mediator yang bersikap netral, dan tidak membuat keputusan atau kesimpulan bagi para pihak tetapi menunjang fasilitator untuk terlaksananya dialog antar pihak dengan suasana keterbukaan, kejujuran dan tukar pendapat untuk tercapainya mufakat. Dengan kata lain, proses negosiasi pemecahan masalah dimana pihak luar yang tidak memihak (impartial) dan netral bekerja dengan pihak yang bersengketa untuk membantu mereka memperoleh kesepakatan perjanjian dengan memuaskan (win-win solution). Mengenai peran dan fungsi kepala desa atau perangkat desa dalam penyelesaian sengketa yang terjadi bahwa mereka harus mampu melakukan tugasnya selaku mediator yang berusaha untuk menyelesaikan sengketa yang terjadi antar warganya.Sengketa baik itu mengenai sengketa lahan, sengketa antar masyarakat, ataupun sengketa rumah tangga. Fungsi mediator disini adalah penengah yang tidak memihak kepada pihak manapun.Semata-mata hanya menjadi sarana membangun komunikasi yang terhambat diantara warga tersebut.Jika dilihat bahwa fungsi mediator yang sebaiknya digunakan oleh perangkat desa, lurah ataupun kepala desa adalah mediator yang sifatnya settlement mediator dengan menggunakan settlement mediasi.Adapun settlement mediasi dikenal sebagai mediasi kompromi merupakan mediasi yang tujuan utamanya adalah untuk 
mendorong terwujudnya kompromi dari tuntutan kedua belah pihak yang sedang bertikai. Dalam mediasi model ini, tipe mediator yang dikehendaki adalah yang berstatus tinggi, sekalipun tidak terlalu ahli dalam proses dan teknik-teknik mediasi. Adapun peran yang dapat dimainkan oleh mediator adalah menentukan "bottomlines" dari disputan dan secara persuasive mendorong kedua belah pihak bertikai untuk sama-sama menurunkan posisi mereka ke titik kompromi. Model settlement mediation mengandung sejumlah prinsip antara lain:

1. Mediasi dimaksudkan untuk mendekatkan perbedaan nilai tawar atas suatu kesepakatan.

2. Mediator hanya terfokus pada permasalahan atau posisi yang dinyatakan para pihak.

3. Posisi mediator adalah menentukan posisi "bottom line" para pihak dan melakukan berbagai pendekatan untuk mendorong para pihak mencapai titik kompromi.

4. Bisanya mediator adalah orang yang memiliki status yang tinggi dan model ini tidak menekankan kepada keahlian dalam proses atau teknik mediasi.

5. Dalam hal ini permasalahan yang kedua adalah ketika bersengketa masyarakat setempat biasanya lari keketua adat, kepala desa atau sesepuh desa. Namun dikarenakan mereka merupakan perorangan, maka seringkali kendala-kendala penyelesaian sengketa terjadi misalnya:

a. Kekurang pahaman terhadap mediasi dan proses mediasi dapat menyebabkan terhambatnya penyelesaian sengketa yang dihadapi.

b. Kepentingan perorangan sering kali menghalangi cepatnya penyelesaian sengketa yang terjadi. ( 
Pemerintah desa Sendang dimana berperan sebagai mediator di dalam menyelesaikan permasalahan pencemaran imbah ternak sapi perah adalah menempatkan sebagai pihak ketiga yang netral dengan mengedepankan pencapaian solusi.Cara yang ditempuh adalah dengan mengadakan musyawarah dari berbagai pihak agar tidak ada pihak yang merasa dirugikan.

c. Pemerintah desa sebagai motivator

Secara umum pembangunan masyarakat desa berdampak pada perubahan tata kehidupan bermasyarakat yang meliputi dua aspek yaitu perubahan secara fisik dan teknologi serta perubahan sistem nilai dan sikap. Jadi pembangunan bukan saja masalah penyedian pelayanan sosial, akan tetapi juga tergantung pada faktor politik, ekonomi, kelembagaan dan budaya yang bersama-sama semakin penting perannya dalam pemberantasan kemiskinan. Dalam proses pembangunan masyarakat, desalah yang paling tahu kebutuhan apa yang diperlukan sehingga perencanaan pembangunan di desa haruslah dimulai dan di rencanakan oleh masyarakat desa bottom up dan tidak top down.

Motivasi merupakan satu penggerak dari dalam hati untuk mencapai suatu tujuan. Dengan kata lain motivasi adalah proses menghasilkan tenaga yang di arahkan untuk mencapai tujuan yang ingin dicapai. Dalam suatu kelompok, motivasi sebagai penggerak kepada kejayaan organisasi.Motivasi memainkan peranan yang sangat penting dalam organisasi termasuk juga dalam organisasi pemerintahan. Dalam hal memotivasi atau memberikan semangat dari hasil penelitian ini warga Desa Sendang memandang atau menilai Peran Kepala Desa ini sudah berjalan dengan baik di mana Kepala Desa Memberikan Motivasi-Motivasi terhadap warga akan pentingnya melindungi alam dan lingkungan dari limbah pencemaran sapi. 


\section{Faktor Penghambat dan Faktor Pendukung Strategi Pengelolaan Limbah Peternakan (Studi di Desa Sendang Kecamatan Sendang Kabupaten Tulungagung)}

a. Faktor Pendorong

Yang menjadi faktor pendorong peran pemerintah desa dalam mengatasi pencemaran lingkungan akibat limbah sapi perah adalah sebagai :

1) Tingginya kesadaran para peternak sapi perah

Adanya penerimaan dan pengakuan dari para peternak sapi perah bahwa masalah limbah sapi perah ini harus ditangani agar keberlangsungan lingkungan tetap terjaga membuat upaya yang dilakukan oleh pemerintah desa bisa berjalan dengan baik.

2) Adanya dukungan dari pemerintah desa

Suatu program tidak akan bisa berjalan dengan baik tanpa adanya dukungan dari pemerintah setempat. Baik penyedian sarana dan prasarana atau juga sebagai pihak yang memediasi apabila ada perbedaan pendapat di antara warganya.

b.Faktor penghambat

Yang menjadi faktor penghambat peran pemerintah desa dalam mengatasi pencemaran lingkungan akibat limbah sapi perah adalah sebagai :

1) Sumber Daya Manusia Perangkat Desa

Usia para perangkat desa yang sudah tidak muda lagi, baik secara langsung maupun tidak mempengaruhi dari peran pemerintah desa itu sendiri. Karena kendala Sumber daya manusia ini menjadikan penyerapan akan pembaharuan teknologi dalam hal pengolahan limbah sapi perah menjadi kurang maksimal.

2) Minimnya Anggaran.

Anggaran merupakan satu hal yang sangat penting dalam pelaksanaan suatu kegiatan. Tanpa adanya dukungan dana yang mencukupi akan mustahil suatu kagiatan bisa terus 
dilaksanakan. Anggaran tidak hanya dibutuhkan pada saat awal kegiatan saja akan tetapi juga dibutuhkan untuk menjamin keberlangsungan kegiatan tersebut.

\section{KESIMPULAN DAN SARAN}

Dari hasil penelitian pada bab sebelumnya bisa di ambil kesimpulan bahwa dalam mengatasi pencemaran lingkungan akibat limbah peternakan sapi di Desa Sendang Kecamatan Sendang Kabupaten Tulungagung adalah sebagai berikut :

1. Peran pemerintah desa sebagai fasilitator yaitu memfasilitasi atau melengkapi kebutuhan, sarana dan prasarana yang mendukung proses pemerintahan dan pembangunan desa. Peran pemerintah desa sebagai mediator yaitu membuat suatu penyelesaian sengketa para pihak dengan kesepakatan bersama melalui mediator yang bersikap netral, dan tidak membuat keputusan atau kesimpulan bagi para pihak. Terakhir Pemerintah desa sebagai motivator yaitu Memberikan Motivasi-Motivasi terhadap warga akanpentingnya melindungi alam dan lingkungan dari limbah pencemaran sapi perah.

2. Faktor penghambat dan faktor pendukung Peran Pemerintah Desa dalam mengatasi pencemaran lingkungan akibat limbah peternakan sapi di Desa Sendang Kecamatan Sendang Kabupaten Tulungagung adalah sebagai berikut :

a. Faktor pendorong : tingginya kesadaran para peternak sapi perah untuk mengolah limbah sapi perah dan besarnya dukungan dari pemerintah desa untuk mendatangkan tenag ahli dalam pengolahan limbah pencemaran sapi perah.

b. Faktor penghambat : sumber daya manusia dari perangkat desa yang mana sebagian besar perangkat desa sudah tidak muda lagi dan minimya ketersediaan anggaran untuk pelatihan pengolahan limbah sapi perah. 


\section{A. Saran}

Berdasarkan kesimpulan yang telah di ambil di atas maka penulis memberikan beberapa saran sebagai berikut :

1. Harus ada usaha yan kongkrit dari pemerintah desa untuk meningkatkan kualitas sumber daya manusia baik bagi warga masyarakat ataupun perangkat desa. Hal ini bisa dilakukan dengan peningkatan pendidikan bagi mereka.

2. Perlu menggali sumber pendanaan lain untuk pengolahan limbah ternak sapi perah ini. Tidak bisa hanya mengandalkan dari pemerintah saja tetapi pemerintah desa harus bisa mengalokasikan baik dari dana desa atau menggandeng pihak ketiga. 


\section{DAFTAR PUSTAKA}

Ahmadi, Rulam. 2014. Metode Penelitian Kualitatif. Ar-Ruzz Media: Yogyakarta.

Crawford, J. 2003. Composting of Agricultural Waste. in Biotechnology Applications and Research. p. 68-77.

Farida E. 2000. Pengaruh Penggunaan Feses Sapi dan Campuran Limbah Organik Lain Sebagai Pakan atau Media Produksi Kokon dan Biomassa Cacing Tanah Eisenia foetida savigry. Skripsi Jurusan Ilmu Nutrisi dan Makanan Ternak. IPB, Bogor.

Ginting. 2007. Penuntun Praktikum Teknologi Pengolahan Limbah Peternakan. Universitas Sumatera Utara Repository. Medan.

Hidayat, N., P. Masdiana dan S. Suhartini. 2006. Mikrobiologi Industri. Penerbit Andi. Yogyakarta. Indroprahasto, S. 2010. Kompos.Balai Penelitian Bioteknologi Perkebunan Indonesia. Bogor. Isroi, 2008. Balai Penelitian Bioteknologi Perkebunan Indonesia. Bogor.

Kaharudin dan F.M. Sukmawati.2010. Manajemen Limbah Ternak untuk Kompos dan Biogas.Balai Pengkajian dan Teknologi Pertanian. Nusa Tenggara Barat.

Nurhasanah. 2005. Biogas Sebagai Energi Alternatif. Penerbit Media Pustaka Press. Jakarta.

Rahayu, E dan S. P. Nur. 2002. Isolasi dan Seleksi Lactobacillus yang Berpotensi Sebagai Agensi Probiotik. Agritech Vol.23 No.2 Hal 67-74.

Suardana, W. 2007. Isolasi dan Identifikasi Bakteri Asam Laktat dari Cairan Rumen Sapi Bali sebagai Kandidat Biopreservatif. Jurnal Veteriner Vol.8 No.4:155-159.

Sofyadi Cahyan, 2003. Konsep Pembangunan Pertanian dan Peternakan Masa Depan. Badan Litbang Departemen Pertanian. Bogor.

Sihombing D T H. 2000. Teknik Pengelolaan Limbah Kegiatan/Usaha Peternakan. Pusat Penelitian Lingkungan Hidup Lembaga Penelitian, Institut Pertanian Bogor. 
PUBLICIANA : JURNAL ILMU SOSIAL DAN ILMU POLITIK

VOLUME 14 NO 1

ISSN : $1979-0295$ | E-ISSN : $2502-7336$

Soehadji, 1992. Kebijakan Pemerintah dalam Industri Peternakan dan Penanganan Limbah Peternakan. Direktorat Jenderal Peternakan, Departemen Pertanian. Jakarta.

Willyan, D. 2008. Langkah Jitu Membuat Kompos Dari Kotoran Ternak. Agro Media. Jakarta

Widodo, Asari, dan Unadi, 2005. Pemanfaatan Energi Biogas Untuk Mendukung Agribisnis Di Pedesaan.Publikasi Balai Besar Pengembangan Mekanisasi Pertanian Serpong. 